University of Michigan Law School

University of Michigan Law School Scholarship Repository

Articles

Faculty Scholarship

1922

\title{
Emotional Disturbance as Legal Damage
}

\section{Herbert F. Goodrich}

University of Michigan Law School

Available at: https://repository.law.umich.edu/articles/993

Follow this and additional works at: https://repository.law.umich.edu/articles

Part of the Law and Psychology Commons, Legal Remedies Commons, Medical Jurisprudence Commons, and the Torts Commons

\section{Recommended Citation}

Goodrich, Herbert F. "Emotional Disturbance as Legal Damage." Mich. L. Rev. 20 (1922): 497-513.

This Article is brought to you for free and open access by the Faculty Scholarship at University of Michigan Law School Scholarship Repository. It has been accepted for inclusion in Articles by an authorized administrator of University of Michigan Law School Scholarship Repository. For more information, please contact mlaw.repository@umich.edu. 


\section{EMOTIONAL, DISTURBANCE AS LEGAL, DAMAGE,}

66 ENTAI pain or anxiety the law cannot value, and does not pretend to redress, when the unlawful act complained of causes that alone." Lord Wensleydale's famous dictum in I,ynch v. Knight ${ }^{1}$ will serve as a starting point for this discussion. His lordship's notion of mental pain is evidently that of a "state of mind" or feeling, hidden in the inner consciousness of the individual; an intangible, evanescent something too elusive for the hardheaded workaday common law to handle. I,ikewise, in that very interesting problem regarding recovery for damages sustained through fright, it is always assumed, tacitly or expressly, that mere fright, alone, creates no cause of action." "The mere temporary emotion of fright not resulting in physical injury is, in contemplation of law, no injury at all, and hence no foundation of an action," says Professor Throckmorton in his admirable discussion in a recent number of the HARVARD LAW REVIEW. ${ }^{3}$

But intimations that all the story has not been heard are to be found even in the language of judges. Thus Kennedy, J., in Dulieu v. White, while using, by authority, "mental" and "nervous" as interchangeable terms, ventures the confession: "I should not be surprised if the surgeon or the physiologist told us that nervous shock is or may be in itself an injurious affection of the physical organism." " It would, I believe, help us in solving legal problems arising from claims for damages arising through emotional disturbance of a plaintiff brought about by a defendant, if we kept ourselves familiar, in a general way at least, with what medical men and psychologists are finding out about emotion and its effect on the human body.

Everyone knows, when he stops to think about it, that being scared is something more than a purely emotional matter; more

19 H. L. Cas. 577.

2 SEDGwick on DaMages, Ed. 9, § 43 f.; Kalen v. T. H. \& I. R. Co., I8 Ind. App. 202; K. T. \& T. Co. v. Bain, I6r Ky. 44; Wyman v. Leavitt, I7 Me. 227; C. \& O. Ry. Co. v. Tinsley, II6 Va. 600; Memphis St. Ry. Co. v. Bernstein, I37 Tenn. 637 .

3 Damages for Fright, 34 HARv. I. REv. 260, 266.

4 [190I] 2 K. B. 669,677 . 
than mere "mental pain." With vivid accuracy, Darwin has described the physical symptoms of fright:" "The frightened man at first stands like a statue, motionless and breathless, or crouches down as if instinctively to escape observation. The heart beats quickly and violently so that it palpitates and knocks against the ribs. $* * *$ That the skin is much affected under the sense of fear we see in the marvelous and inexplicable manner in which perspiration immediately exudes from it. $* * *$ In connection with the disturbed action of the heart, the breathing is hurried. The salivary glands act imperfectly. *** One of the best marked symptoms is the trembling of all the muscles of the body, and this is often first seen in the lips. $* * *$ As fear increases into agony of terror, we behold $* * *$ diversified results. The heart beats wildly, or may fail to act and faintness ensues; there is a death-like pallor; the breathing is labored. *** All the muscles of the body may become rigid, or may be thrown into convulsive movements. *** Great beads of sweat stand on the skin. All the muscles of the body are relaxed. Utter prostration soon follows, and the mental powers fail. ***”

It would almost seem that symptoms of this sort were sufficiently objective, even for the common law. But in addition to these external manifestations, the accuracy of. which can no doubt be corroborated by the personal observations and experience of any one, scientists of the very type mentioned by the learned justice, physiologist and surgeon, have marked out recently, in the unexciting atmosphere of the laboratory and the hospital, deeper and more significant effects of strong emotion upon the human organism. Dr. Walter B. Cannon, professor of physiology at Harvard, and Dr. George W. Crile, professor of surgery at Western Reserve, and visiting surgeon to Lakeside Hospital, Cleveland, each an eminent authority in his field, have put forth the results of their researches in non-technical language. ${ }^{6}$

5 Darwin, EXPRESSIONS of EMOTION IN MAN ANd ANIMALs (quoted by Crile, pp. 26, 27, 28).

- Cannon, Bodmy Changes in Pain, Hunger, fear, and Rage; Crife, The Origin and Nature of the Emotions, These will be cited, respectively, as "CAnNoN" and "CrILE." Reference should also be made to another book by DR. CRILE, "MAN-AN Adaptive Mrchanism," which covers much of the same ground. 
It is clearly demonstrated that it is impossible to have fear as a purely emotional thing. "We fear not in our hearts alone, not in our brains alone, not in our viscera alone-fear influences every organ and tissue." Broadly stated, the effect of fear is to put the entire power of the body in shape for fight or flight. All bodily functions which do not directly assist this process are slowed down or stopped. ${ }^{8}$ Have we not all seen a scared orator forget his speech? All functions concerned in the motor reaction are stimulated and invigorated. Fear, in other words, puts the whole human body on a war basis. Ordinary peace time industries slacken, emergency production works overtime. ${ }^{9}$

Dr. Crile believes the phenomena of fear to have a phylogenetic basis. In the long history of the race, fear was created by trauma, actual wounding and bloodshed. Nature gradually built up for the protection of the species a wonderful defensive motor mechanism. Fear then comes to one as a representation of trauma, and causes a discharge of the nervous system by the law of phylogenetic association.10 While our mode of life, our habits, our manners, have changed, the physical mechanism of the body has not. Tonight's passenger in the luxurious Pullman car, awakened from slumber by the hiss of steam, the splitting of timbers and cries of the injured in a railroad wreck, has the same physical reaction for his fear as his prehistoric ancestor, battling bare-handed for his very life with his enemies of the jungle.

The explanation of the origin of these fear phenomena is theory. Its soundness is not in issue here. The phenomena themselves have been shown by scientific demonstration to exist. In the large they have the effect of clearing the decks for action. By omitting description of the patient laboratory methods by which the facts were found, the individual phenomena can be briefly but specifically described.

Fear breaks in upon the digestive processes, directly and quickly. The flow of saliva is arrested, and the mouth becomes dry; gastric

7 CRIIE, p. 60.

${ }^{8} \mathrm{CrIHE}, \mathrm{p} .30$. This is not true, the author states, in cases involving voluntary expenditure of muscular energy, as in the chase.

${ }^{\circ}$ Cannon, p. 269.

${ }^{10}$ CrIIE, pp. 30, 59, et seq. 
juice secretion stops in the stomach; further down the alimentary tract, the flow of pancreatic juice and bile is checked. ${ }^{11}$ Food digestion is not an essential industry in war time, evidently, and the forces employed in it get no occupational exemption. The plant closes down with the material on hand (undigested food) unfinished. Not only are digestive secretions discontinued, but peristaltic action, that peculiar wormlike wave motion of the organs in the digestive process, is suspended as well. ${ }^{12}$ Involuntary voiding of the contents of the bladder and digestive tract often accompany the phenomena just mentioned. ${ }^{13}$ Any soldier who has participated in an infantry attack will give direct evidence on this point. Readers of Kipling will remember Private Mulvaney's description as he relates the battle of Silver's Theatre. The child-welfare people, in measuring and testing babies, always prefer to go to the child's home where possible. The emotional disturbance of strange surroundings causes such increased activity in eliminative functions that the work of the examiner cannot go on, or at best proceeds with difficulty.

What is true of the digestive tract holds good elsewhere. There is an inhibition of the functions of all organs and tissues which consume energy, but which do not make a direct contribution to motor efficiency-fight or flight. ${ }^{14}$

Even more striking than this departure from normality in peace time functions is the effect of fear on those organs which can be used to help the organism in struggle or escape. Sympathetic discharges, probably aided by adrenal secretion, drive the blood from the internal organs into the skeletal muscles. ${ }^{15}$ This, with the accelerated heart action, insures an abundance of blood supply, and sweeps away the products of wear and tear which, if allowed to accuimulate, would impair efficiency. Dr. Cannon's experiments have shown that under the stress of fear the supply of blood sugar is greatly increased, ${ }^{16}$ that the blood itself clots more rapidly, ${ }^{17}$ and that these phenomena are aided by the increased activity of the

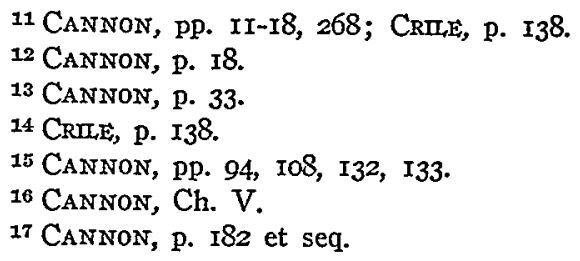


adrenal glands responding to the stimulus. Adrenin thus secreted also restores the fatigued muscles. ${ }^{18}$ The thyroid, another ductless gland, is, in fear, also aroused to increased action. ${ }^{19}$

Fear then is a physical thing. It has been demonstrated as a fact that in a state of fear we have (to paraphrase Crile) (I) a mobilization of the energy-giving compound of the brain cells, evidenced by an increase of the Nissl substance, ${ }^{20}$ and a later disappearance of the substance and deterioration of the cells; (II) increased output of adrenin, of thyroid secretion, of glycogen and an increase of the power of oxidation in the muscles; (III) accelerated circulation and respiration with increased body temperature; (IV) altered metabolism. ${ }^{21}$

What is true of fear is true, to a lesser degree, of other emotions. Fear and anger are very closely akin. And grief, worry, anxiety also have similar effects, the extent depending, of course, on the length and intensity of the emotion. ${ }^{22}$ In fact, it may be broadly stated that an emotion as a purely mental thing does not exist. It always has a physical side. Whether it is a wholly physical matter, or whether the mental state parallels the physical, or whether one causes the other, need not be fought out here.

Granted all this is true, does it affect our legal problem in any way? It does show that judicial language formulated, at a time when no one knew so much about the human organism as we do now, was inaccurate. But suppose we admit that fear, or grief, or humiliation is a physical thing, does it thereby become any easier for the law to handle? The answer is "yes." The question now becomes a question of hard facts, and the common law prides itself on dealing with hard facts. The questions of fact now to be answered are two: (I) does this physical effect of emotion do any harm to the organism, which we can call legal damage? (2) is there any way we can estimate it, so that an assessment of money damages, the only remedy we can give, will not be too purely guesswork?

18 CANNON, p. I28-I33.

19 CRILE, p. I33.

20 Elsewhere explained by CRILE as possibly a volatile combination of certain elements of the brain cells and adrenalin. See p. 202.

21 CRIE, p. I38.

22 CRILE, p. I39; Cannon, p. 275. 
One must be careful not to be led astray on the first question Just because we can hear emotional results described in physical terms in the technical language of the physiologist, it does not follow that they do any material harm to the individual. Dr. Cannon, by analysis of samples of urine of players on the Harvard football team, following the Yale game, and that of students after hard examinations, found the increase in blood sugar following emotion. He did not suggest that the game or the examination hurt either player or student. Dr. Cannon showed, too, that adrenin secretion promoted by emotional stimulation will reinvigorate a muscle as much in five minutes as rest will in the course of an hour. It would seem then that the tired business man guesses right when he chooses the excitement of a whirly-girly show, instead of going home to bed. We might argue that a defendant who has aroused plaintiff's fears and increased his adrenin supply has done him a service, has given him more pep, and ought to be thanked instead of sued.

But harm does result from the emotional state owing to the subject's inability to put strong feeling into action. When nature built up the elaborate physical reactions accompanying fear, to be scared meant to fight or run. Now it seldom means either. Yet the bodily reaction remains unchanged. When fear is followed by the muscular response of a struggle or flight the various products of stimulation are used up. But where the stimulation is not followed by action, these rich power-giving secretions, sugar, adrenin, and all the rest, must be eliminated as waste. ${ }^{23}$ The body under the stimulus of fear may be likened to an automobile with the accelerator pressed down and the throttle opened wide, spark up. The machine is then in shape for effort to the limit of its capacity. But suppose the clutch is thrown out, and the machinery left running. The gasoline is being used up, the machine worn, shaken, and weakened. The batteries (corresponding to the human brain) will more than likely be hit first, then one by one the weaker parts are affected. ${ }^{24}$ If it is a strong machine, the damage will not be instantly noticed by the casual observer, but it is there just the same. If the machine

23 CRILE, pp. 93, I39.

24 CRIIE, pp. 6r, I39-I40, r6r. 
has a weak part, (like a man with hardening of the arteries, the crash may come at once. ${ }^{25}$

It is then true that the effect of fear is harmful to the human organism, especially since in modern times it cannot be followed by action. ${ }^{26}$ The effects, in exhausting nervous energy, are the same as those of trauma. Both drain the cup to the dregs. ${ }^{27}$ Stated in scientific physical terms, fear, without resulting activity, leads to the following definite results: the increase in adrenin may produce arteriosclerosis and cardiovascular disease if the strain is prolonged; the glycogen produced may lead to diabetes. It is said for instance that "When stocks in New York go down, diabetes goes up." Nephritis may follow from the elimination strain on the kidneys; increased heart action may cause myocarditis and heart degeneration. Claudication may also result from impaired circulation. Arresting of the digestive processes causes putrefaction and autointoxication, and further strain on the organs of elimination. Changes in saliva occur, pyorrhea develops, teeth decay. Grave's disease may develop from overproduction of thyroid. Actual changes in brain cells take place-irreparable destruction if the stimulus is strong enough.

It is then clear that fright as definitely affects the physical organism as does a blow with a club. With no desire or volition on the part of the individual ${ }^{28}$ he may suffer very marked physical effects as a result of fear, and effects that are very harmful to him. And what is true of fear is true in kind, though not in degree, of the lesser emotions such as worry and anxiety.

If the physical effect of strong emotional disturbance is a result that we can trace and can see, it should be clear that the plaintiff's right to recover for such disturbance should be recognized. The measurement of the injury in terms of money is no more difficult a problem here than in any case of non-pecuniary damage-a broken leg or a bruised head. The question is simply whether a certain

${ }^{25}$ See Cannon, p. 94.

${ }_{26}$ "The fact that emotion is more injurious to the body than is muscular action is well known." CRILE, p. 93.

${ }^{27}$ CRM,E, pp. 30, 47, et seq., 75.

28 CANNON, p. 185. "The most significant feature of these bodily reactions in pain and in the presence of emotion-provoking objects is that they are in the nature of reflexes-they are not willed movements." 
act produced a given effect, the same question as in the tracing of paralysis from a contusion suffered months before in a street car accident, ${ }^{29}$ or finding whether tuberculosis developed from an injury in a railroad wreck. ${ }^{30}$ The cases which do allow recovery for physical injuries sustained through fright, negligently inflicted, even without physical impact, seem emphatically right. Indeed, the only argument to the contrary that has ever seemed worth much, ${ }^{31}$ the practical difficulty of distinguishing between true and false claims, the danger of fraud through simulated injuries, has been thrown away by the very courts which set it up. Recovery has been allowed where there has been physical impact, but it has been frankly said that where there has been impact the damages recoverable are not limited to those resulting therefrom. ${ }^{32}$ The magic formula "impact" is pronounced; the door opens to the full joy of a complete recovery. Impact may mean anything, dust in the eyes, ${ }^{33}$ a forcible seating on the floor. ${ }^{34}$ Further, if the defendant's act is intentional, no impact is necessary, whether the act be one intended to result in physical battery, ${ }^{35}$ merely to stir up an emotional response, ${ }^{36}$ or a wrongful entry into another's home. ${ }^{37}$ In such cases there is a difference in the defendant's conduct as contrasted with mere negli-

${ }^{29}$ Bishop v. St. Paul City Ry. Co., 48 Minn. 26.

${ }^{30}$ Gray v. C. \& N. W. Ry. Co., I53 Wis. 637.

31 These various arguments are set out and discussed in the Throckmorton article cited supra, note 3 , and by Professor Bohlen, "Right to Recover for Injury Resulting from Negligence without Impact," 4I AMr. L. REG. (Old Series 50), p. I4I; see further Professor Drake in Ig Mrch. L. Rev. 365,368 . A collection of cases may be found in 3 L. R. A. n. s. 49 .

32 Homans v. Boston R. Co., I80 Mass. 456; Driscoll v. Gaffey, 207 Mass. ro2.

${ }^{33}$ Porter v. D., L. \& W. R. Co., 73 N. J. L. 405.

34 Driscoil v. Gaffey, stppra. See comment upon this decision in Spearman v. McCrary, 4 Ala. App. 473.

35 Holdorf v. Holdorf, 185 Iowa 838.

${ }^{36}$ Wilkinson v. Downton, [1897] 2 Q. B. 57; Janvier v. Sweeney, [1919] $2 \mathrm{~K}$. B. 3I6, with comments citing authorities in 33 HARv. I. REv. 324,68 U. of P. L. REv. I76, I8 MICH. L. REv. 332. See cases on recovery for physical suffering sustained by threats on the part of defendant, 5 A. I. R. I283. ${ }^{37}$ Watson v. Dilts, II6 Iowa 249; Mollman v. Union Elect. Co., (Mo. I92I) 227 S. W. 265, commented upon in 19 Mich. L. REv. 76r. Cf. Boyce v. Greeley Sq. Hotel Co., 228 N. Y. I06, where entry was into plaintiff's hotel room; commented upon in 5 CORNEI, I. Q. 489. 
gence on his part, but where is the difference in the plaintiff's injury or the danger of simulation? The problem of tracing from cause to effect, the difficulty of distinguishing true from false, seems equally present, irrespective of the moral culpability of the defendant. ${ }^{38}$

There are no doubt numberless instances where a plaintiff's economic interests obscure his perception of the truth regarding injuries suffered at a defendant's hands. The danger of lying, medical men have said, is admittedly greater in cases of so-called nervous disorders, because so murh of the evidence must necessarily come from the patient himself, and is not easy of external verification or repudiation. ${ }^{39}$ This, be it noted, is not a problem peculiar to damage without impact. It covers the whole field of bodily harms. Yet no one seems to have advocated a general refusal to permit recovery for nervous disease because of the difficulty of proving that a particular plaintiff is lying about his complaint. Skilled medical men have developed a technique for distinguishing the real sufferer from the fraudulent imposter. The devices by which this technique is called into operation for detection of the dishonest are too elaborate to set out here. On the general question, however, a statement such as the following from Sir John Collie is in point: "It should always be remembered that the patient is at a great disadvantage compared with the doctor, in that he has not the latter's special knowledge; and if he is lying and endeavoring" to make up symptoms which he thinks suitable to the case, he will produce a picture so distorted, so lacking in verisimilitude, that its falsity is manifest. *** He may often, in fact, be exposed by asking whether he experiences which might appear to the lay mind as likely to occur, but which the expert knows are utterly foreign to the ordinary consequences of the accident in question."

"Malingerers are not so foolish as to come for medical examination without having considered beforehand how they shall counterfeit the disease they propose to suffer from. But even so, the inter-

38 See, however, Dean Pound's discussion in "Interests of Personality," 28 HARv. L. Rev. 343, 359, et seq.

39 Colim, Malingering, I04, I29. The writer says, p. 34, that "the difficulties which defendants have in refuting unjust or exaggerated claims are enormous." He is referring to the general problem of malingering, however. 
view is a contest in which a skilled and experienced investigator is pitted against an ignorant and crafty rogue, and in the long-run the issue should be certain."

It is submitted then that whenever a wrongful act by a defendant creates an emotional disturbance in a plaintiff from which injurious physical consequences can be found as a fact to have resulted, the right to recover is complete, unless some affirmative defense is made out. The apprehension that such a doctrine puts innocent persons at the mercy of the emotionally unstable folk who are the minority of the community - a fear which has found judicial expression more than once ${ }^{40}$ - should have been soothed by the clear analysis which Professor Bohlen has made of the problem of damage without impact. ${ }^{41}$ Take a hypothetical case. A, in a condition of partial intoxication which slightly interferes with his locomotion, meets a woman on the sidewalk. He does nothing. But she becomes frightened at him, suffers a shock, subsequent miscarriage, nervous prostration, other ills $a d l i b$. But $A$ is not liable merely because he has frightened this woman and caused her harm. The element of culpability is not yet shown to exist. ${ }^{42}$ Foreseeability of harm from what one does is the proper test for the existence of negligence, however incorrect it is in determining the limit of liability for consequences where negligence is proved.33 "The jury $* * *$ must put itself in the defendant's place at the time he acted and judge of his action by the probable consequences of it. If no harm were then probable the act does not become negligent because injury actually follows. ***"44 If the proper emphasis is placed, in instructing juries, on the requirement that defendant be guilty of either wrongful intent or negligent conduct, the negligence tested by what a man of ordinary prudence could have anticipated at the time the act was done, and if the court will be firm in refusing to leave to the jury cases where, judged by the standard mentioned,

${ }^{40}$ Spade v. Lynn \& B. R. Co., r68 Mass. 285.

${ }^{41} 4 \mathrm{I}$ Am. L. REg. (Old Series 50), pp. 147 et seq., r68. And see PoL.IOCK ON TORTS, Ed. 9, 53.

42 This point, kept in mind, would care for some of the cases that labor, with unnecessary difficulty, on the mental suffering element. See, for instance, Haas v. Metz, 78 1II. App. 46.

${ }^{43}$ Smith v. London \& S. W. Ry. Co., L. R. 6 C. P. I4.

44 Bohlen, 4I AM. L. REG. (Old Series 50) 147. 
there is no evidence from which negligence could be found, there seems slight danger that defendants will be placed at the mercy of the hysterical, the morbid, or the emotionally unbalanced.

In addition, the negligence must be a violation of duty to this plaintiff. "Actionable negligence is the failure to discharge a legal duty to the person injured."45 Presumably the cases denying recovery to one suffering injury through fear for the safety of another are to be justified, if at all, on this ground. ${ }^{48}$

Striking as the recent work of the physiologist and psychologist has been, there is a vast deal to be done before the scientist can give to the law facts enough to settle the questions arising from claims for what, for want of a better term, we call mental suffering. Every emotional state, we are told, has its concomitant physical manifestations. With some of the stronger emotions, such as fear, harm-

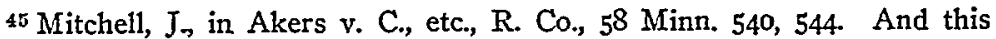
would explain Chittick v. Phil. R. T. Co., $224 \mathrm{~Pa}$. I3, where defendant was negligent, but not to this plaintiff. The principle was misapplied, however, in Brooker v. Silverthorne, 99 S. E. 350, 5 A. L. R. 1283, where the wrongfui act of the defendant consisted of threats and abuse.

${ }_{46}$ Thus in Dulieu v. White, [Igor] 2 K. B. 669 , Kennedy, J., says: "A has, I conceive, no legal duty not to shock B's nerves by the exhibition of negligence to $\mathrm{C} * * *$ Ample authority supports the view that if physical injuries through fear are to be recovered for, the fear must be for one's own safety. See cases cited, p. 53 Pound's edition of Amrs \& SMimH, CASES oN Torts. Can we not conceive of situations where A's putting $C$ in danger might of itself be such negligence to $B$ that $B$ could recover for injuries from the accompanying shock? The law goes much further than this in one line of cases, of which Eckert v. L. I. R. Co., 43 N. Y. 502, is most frequently cited. (See I BoHLEN's CASES on ToRis 345 for further cases.) $\mathrm{C}$ is in danger through $\mathrm{A}$ 's negligence. $\mathrm{B}$, attempting to rescue $\mathrm{C}$, is injured. $B$ is allowed recovery against $A$. The discussion of these cases proceeds largely on the question of B's contributory negligence. But after that is settled, there must be found negligence to $B$, on the part of $A$, to allow him damages. We must say, must we not, that it is negligent, as regards $B$, carelessly to put $C$ in such a position of danger that $B$ is hurt in the attempted rescue?

Is it too much to say that it is wrongful conduct to $B$ to put $C$ in danger, or threaten $C$ with harm, especially if $B$ and $C$ are husband and wife, or parent and child? There would seem to be something in those cases that say consequences of fear may be actionable, even where the fear is for another. See Hill v. Kimball, 76 Tex. 210; Engle v. Simmons, I48 Ala. 92; Watson v. Dilts, II6 Iowa 249; 3 Mrnn. L: Rev. 539. 
ful physical effects have been demonstrated. Some time we may, likely shall, have means for detecting the beneficial or harmful effects of all emotional stimuli. Here we must wait for the scientist. If he can tell us when an emotional stimulus is innocuous or even beneficial to the organism, and at what stage the stimulation causes harm, we shall have something definite to go on. But we are a long way from that now in distance to go, if not in time to wait. Even with fright, the effects of which have been most intensively studied, there are thousands of instances where the effect of being moderately scared for a short period of time cannot be measured in a damaged physical organism. Even Dr. Crile would not attempt to estimate the harm done the body through the fearful anticipation of an appointed trip to the dentist. So while we may look with "interest and sympathy," perhaps even with eager anticipation, for more light from the scientist, the law "must continue to deal with mental suffering as a practical problem of its own. Without the possibility of proof that a certain unpleasant emotional experience has resulted in actual physical harm to the individual who suffered it, is it going to be enough to allow recovery of money damages that a wrong-doing defendant has disturbed our plaintiff's peace of mind?

Upon this subject the law today is in that state of affirmation in one situation, and denial in another not distinguishable from the first, which shows a change in process of taking place, but not yet accomplished. We find the supreme court of Georgia declaring that "Wounding a man's feelings is as much actual damage as breaking his limbs," of recovery "would be a reproach to the law."48 Almost simultaneously we find Georgia's picturesque word painter, Mr. Justice Lumpkin, asserting that the law does not protect feelings. "The law leaves feeling to be helped and vindicated by the tremendous force of sympathy. $* * *$ The civil law is a practical business system dealing with what is tangible, and does not undertake to redress psychological injuries." 49

It would be entirely conceivable to have the law settled that emo-

47 Head v. Ga. Pac. Ry. Co., 79 Ga. 358.

48 Douglas v. Stokes, I49 Ky. 506.

19 Chapman v. Telegraph Co., $88 \mathrm{Ga} .763,772$. 
tional disturbance is too delicate a harm to attempt to cure with the rough remedy of money damages. How can money measure the grief caused by the mutilation of the body of a dear one? And, further, how can a jury tell the extent of fright, humiliation, shame and other "psychological injuries"?

But the law has not stopped at this point, and in going beyond it is now in a position which can hardly be logically justified, either by radical or conservative. That a plaintiff's recovery must be in money damages need cause us little more difficulty in cases of emotional disturbance than in any other instance of non-pecuniary loss; the pain of a shattered foot, the loss of reputation from a defamation, the loss of liberty from false imprisonment. A judgment for money is a clumsy device, but it is the best the law has. ${ }^{50}$

Pious incantations about recovery for emotional disturbance being "too remote, uncertain and difficult of ascertainment" lose their charm when we remember how far courts have already gone in making injured feelings a matter of recovery. In connection with proved physical injury, wrongfully caused, it has long been an element in recovery, not merely where undistinguishable from "physical pain," "or but in further removed situations, where it takes the form of humiliation for disfigurement, ${ }^{53}$ loss of sexual power, ${ }^{54}$ and the like. It may well be, as Professor Bohlen has suggested, that the practice of including this element in recoverable damages arose at a time when courts were not able to force their conceptions of legal injuries on juries, ${ }^{55}$ that one reason for continuing to recognize it is that the jury always will include it, whether they should do so or not. ${ }^{63}$ The main point here is that the emotional injury is compensated. Other instances where "mental suffering" is a recoverable item of damages in connection with a cause of action already recognized at law are frequent and well known. The injury aside

${ }^{60}$ See Merrill v. Los Angeles, etc., Co., I58 Cal. 499.

${ }^{51}$ St. L., I. M. \& So. Ry. Co. v. Taylor, 84 Ark. 42.

62 See the Arkansas case in last note; and Head v. Ga. Pac. Ry. Co., 79 Ga. 358 .

53 Merrill v. Los Angeles, etc., Co., 158 Cal. 499; Newbury v. G. \& M. Co., I0o Iowa $44 \mathrm{r}$.

64 Normile v. Wheeling Traction Co., 57 W. Va. I32, 68 I. R. A. gor.

65 See article referred to in note 32.

${ }_{50}$ Merrill v. Los Angeles, etc., Co., I58 Cal. 499. 
from this element need not be substantial. It is sufficient if the cause of action exists as a peg to hang the parasitic element upon. Thus the mental injury is assessed in cases of assault, ${ }^{57}$ in malicious prosecution,,$^{58}$ in defamation, ${ }^{50}$ in wrongful arrest, ${ }^{00}$ in seduction, ${ }^{61}$ in unlawful search and seizure, ${ }^{62}$ and has even been allowed when tied up with trespass q. c. f. ${ }^{03}$ One who is at law entitled to custody of a corpse is entitled to compensation for grief caused by intentional mutilation, but, according to many authorities, not when the conduct is merely negligent-(though, pray, why not?) ${ }^{\text {e4 }}$ But no matter how close the relation to the deceased, if the right of burial is in another, no recovery is to be had. ${ }^{65}$ The peg is missing.

There are many more-the telegraph cases, now of little practical importance since contracts limiting liability have been so authoritatively upheld, ${ }^{66}$ breach of promise suits, ${ }^{67}$ even an occasional case of pure contract. ${ }^{68}$ An exhaustive array of all the situations would serve no good purpose here.

Such an allowance of damages as, here described puts an end to discussion about impossibility of adjusting compensation, and also of any talk about the nature of the subject matter being too speculative for the law to recognize as an interest to be protected. It is protected when we have damage to some other interest hooked up with it to redress at the same time.

Mr. Street has said:"0 "The treatment of any element of damage as a parasitic factor belongs essentially to a transitory stage of legal evolution. A factor which is today recognized as parasitic will,

${ }^{87}$ McKinley v. C. \& N. W. R. Co., 44 Iowa 3 I4.

${ }^{58}$ Parkhurst v. Masteller, 57 Iowa 474.

50 Swift v. Dickerman, 31 Conn. 285 .

${ }^{60}$ Young v. Gormley, I20 Iowa 372.

01 Hawn v. Banghart, 76 Iowa 683 .

62 U. S. F. \& G. Co. v. State, (Miss.) 83 So. 6 ro, commented upon in 6 VA. L. REv. 599 .

${ }^{63}$ Meagher v. Driscoll, 99 Mass. 28r.

64 The most recent collection of these decisions may be found in a note, I2 A. I. R. 342. See also 28 YALE L. J. 508; 28 . HARv. L. Rev. 322.

65 Floyd v. Atlantic Coast Line R. Co., (N. C.) 83 S. E. 12.

${ }^{B B}$ See citation of authorities, 5 Iowa LAw BULLETIN 280.

${ }^{07}$ Geiger v. Payne, 102 Iowa 58I; Rime v. Rater, I08 Iowa 6I.

${ }^{68}$ Lewis v. Holmes, I09 La. I030; Smith v. Leo, 36 N. Y. S. 949.

${ }^{89}$ StreEt, Foundations of Legal LiabiLity, 470. 
forsooth, tomorrow be recognized as an independent basis of liability. It is merely a question of social, economic, and industrial needs as those needs are reflected in the organic law."

May we not expect to see, soon, a breaking away from the rule of thumb requiring emotional disturbance to be coupled with something else before redress is given ?to It is interesting to note the tendency in other actions than those for the recovery of money judgments. Any recent discussion of cruelty as a ground for divorce shows how far decisions go in considering acts of emotional disturbance as cruelty. ${ }^{71}$ There are some recent decisions in the law of nuisance that are particularly striking. Injunctions against smells, noises, dangerous storage of explosives, we are long familiar with. But we find several recent cases where relief has been given against things whose sole offensive quality was disturbance of the complainant's peace of mind. Thus a small tuberculosis hospital was called a nuisance, not because it was a danger to health from contagion, for it was shown by scientific evidence that there was no such danger, but because the plaintiff, as a not unduly sensitive person, feared it. ${ }^{2}$ A cancer hospital in Kansas got the same treatment. ${ }^{73}$ "The question is not whether the establishment of the hospital would place the occupants of the adjacent dwellings in actual danger of infection, but whether they would have reasonable ground to fear such a result. ***" The unpleasantness of the hospital and the fear it inspires may alone be enough of themselves to make it a nuisance. Of course these elements are make-weights where there is noise or smell. ${ }^{74}$

One would expect to find undertaking parlors declared a nuisance

70 See an argument for this proposition, I7 MICH. L. REv. 407.

${ }^{71} 9$ R. C. I. $34 \mathrm{I}$ et seq.; ig C. J. 49 et seq.

72 Everett v. Paschall, 6I Wash. 47. Cf. Board of Health v. North Amer. Home, 77 N. J. Eq. 464, where the court refused to declare a nuisance a hospital for treatment of tuberculosis of the bone, saying "if no real danger *** exists, the mere fact that uninformed people *** may or probably will assume such a danger to exist cannot be made the basis for equitable relief."

${ }^{73}$ Stotler v. Rochelle, 83 Kan. 86. Cf., a leper case, Baltimore v. Fairfield Imp. Co., $87 \mathrm{Md}$. 352 .

74 Deaconess Home v. Bontjes, 207 Ill. 553; Kestner v. Homeopathic Hosp., 245 Pa. 326; Barth v. Christian Psychopathic Hosp., I96 Mich. 642. 
if they were a source of contagion to neighbors. But several recent cases have declared them a nuisance in residence districts, not from the danger of disease, but because of their effect on the minds of the people in the neighborhood. Says the Washington court: "It may be accepted as within the common knowledge of man, that the immediate presence of these mute reminders of mortality, the hearse, the chapel, the taking in and carrying out of bodies *** cannot help but have a depressing effect upon the mind $* * *$ '7s

We have, too, many things declared nuisances because they shock the moral sense of the community-profanity, bawdy houses, public breeding of animals. Is this not another instance of the law's recognition of undisturbed feelings as a matter for protection?

We need not be duly alarmed that a wider protection to the feelings will open up the flood-gates of litigation to redress all petty annoyances. The courts will be guided by the same good sense that aids them in drawing distinctions in the nuisance cases. It is not every smell, every racket, that constitutes a nuisance. So it would not be every emotional upset that need constitute the basis for a lawsuit. The sensation of fright is generally a transitory thing; when without measurable effects, it might be declared too trivial to bother with. ${ }^{76}$ Mere annoyance is likewise relatively unimportant-indeed, is not now to be considered, generally, as a parasitic element of damages. ${ }^{77}$ And so with others. There need be little apprehension that the older and more conservative members of a conservative profession, the judges who make up the body of our appellate courts, will be unduly hasty in extending protection against injured

75 Densmore v. Evergreen Camp No. I47, 6I Wash. 230. Accord: Goodrich v. Starrett, (Wash.) 184 Pac. 220, commented upon in 33 Harv. L. Rev. 6r3; Saier v. Joy, Ig8 Mich. 295, commented upon in 4 IowA Law Bulletin 63. In Westcott v. Middleton, 43 N. J. Eq. 478,44 N. J. Eq. 297, it was thought that plaintiff's trouble came from undue sensitiveness. Cemeteries, however, are not considered nuisances merely because they are "memorials of death." See cases cited, note 3I L. R. A. (n. s.) 946. Several of these cases emphasize the attractive arrangement of most cemeteries. The North Carolina court suggests that "the suggestions thus occasioned would, in the end, be of salutary influence." Ellison v. Commissioners, $58 \mathrm{~N}$. C. 57.

76 See the article by Bohlen above referred to.

77 Sengwick on Damages, Ed. 9, § 42. But see S. W. Tel. \& Tel. Co. v. Riggs, 216 S. W. 403 , with comment in 68 U. of PA. L. REv. 367. 
feelings further than principles either of justice or expediency call for.

While we may expect much help from men of science in supplying us with facts about the nature of man's emotions and its bodily effects, and perhaps in measuring for us the strength of the various emotions, the legal effect of the facts must ultimately rest on rules of policy as laid down by courts and legislatures. It is submitted that the law has already recognized the possession of a peaceful mental state as a subject for protection. It now only remains to break loose from the arbitrary rule requiring such protection to be coupled with some other claim before affording redress. This step, it is submitted, we may see taken any time. That is the way the common law grows.

Jowa City, Iowa

HERBERT F. GOODRICH. 